INTERNATIONAL JOURNAL OF RESEARCHES IN BIOSCIENCES, AGRICULTURE AND TECHNOLOGY (C) VISHWASHANTI MULTIPURPOSE SOCIETY (Global Peace Multipurpose Society) R. No. MH-659/13(N) www.vmsindia.org

\title{
ISOLATION OF BACTERIAL PATHOGENS FROM LOCAL FISH MARKET OF WARORA CITY, MAHARASHTRA, INDIA.
}

\author{
R. R. Kamdi ${ }^{1}$ and P. R.Bhandari ${ }^{2}$ \\ ${ }^{1}$ Anad Niketan College, Anadwan, Warora-442914 \\ ${ }^{2}$ Sewadal Mahila Mahavidyalaya, Nagpur \\ kamdi.ramdas@gmail.com
}

\begin{abstract}
:
Present study tried to verify the occurrence of pathogenic microorganisms among the fresh water fishes (Channa and Catla spp.) and prawns, collected from local markets in Warora city of district Chandrapur (MS), India. Most of the samples were found to be seriously contaminated with pathogenic bacteria ranging from $1.6 \times 10^{5}$ to $6.7 \times 10^{9}$ $\mathrm{cfu} / \mathrm{g}$. Fungal growth was also detected in all samples within a range of $1.3 \times 10^{4}-3.8 \times 10^{6} \mathrm{propagules} / \mathrm{g}$. The study of antibiogram illustrated a number of pathogenic isolates to be drug-resistant. Such a prevalence of pathogens including the antibiotic resistant ones among the studied fish samples may assert a severe public health menace.
\end{abstract}

Keywords: Local fish market, Pathogenic bacteria, Channa spp., Catla spp., Prawn, Antibiogram

\section{Introduction:}

Humans and animals have been utilizing fish as a major food component. Fishes are known to be enriched by high nutritional components and concentrated source of energy (Mead et al., 1986; Mol et al., 2007; Dinakaran et al., 2010; Kawarazuka, 2010). Dominant varieties of fishes such as Channa sp., Catla sp. and prawns (Penaeus monodon) are routinely catches from nearby water bodies and sold in the local market. These fishes and prawns are rich in nutritional values and have a vast popularity amongst the native people.

A variety of fishes consumed regularly are prone to pathogenic spoilage especially by Vibrio spp., Shigella spp., Salmonella spp., Streptococci, Staphylococci, coliforms, Listeria spp., Clostridium spp. which may get entry into the fish from their habitat or during the fish transportation and storage (Frazier and Westhoff, 1995; Eze et al., 2010). A number of reports suggested that the consumption of the microbiologically spoiled foods might be responsible for food-borne diseases like diarrhea, salmonellosis, shigellosis, cholera and even some neurological diseases by an array of viruses, bacteria, fungi and parasites (Snowdon et al., 1989; Starutch, 1991; Karunasagar et al., 1994; Cray and Moon, 1995; Wallace et al., 1999). Thus, with the growing importance of fishes and prawn as the major food items, it is worth to maintain the microbiological quality of these products. Therefore, it is crucial to estimate the rate of microbial spoilage and to establish the preventive strategy to ensure the general food safety.

Along these lines, present study examined the pathogenic prevalence among locally available Channa and Catla fish samples and prawn samples. The antibiotic resistance patterns of the isolated pathogens were also determined.

\section{Material and Methods:

Study area, sampling and sample
processing

Ten each of Channa sp., Catla sp. and prawn samples were collected from weekly local market of Warora city in sterilized polythene bags aseptically within January, 2013 to May, 2013 at an approximate interval of one month. Ten grams of each sample was transferred to 90 $\mathrm{ml}$ of sterile normal saline and was homogenized. The homogenized suspension was subjected to serial dilutions (10-fold) up to $10^{6}$ with normal saline.

\section{Assay of pathogenic load}

$0.1 \mathrm{ml}$ of each sample was spread onto Membrane Fecal Coliform (MFC) nutrient agar, Sabouraud Dextrose Agar (SDA) and Manitol Salt Agar (MSA) for enumerating total viable bacteria (TVB), total fecal coliform (TFC), fungi and Staphylococcus aureus, consecutively. For TVB and staphylococcal assay, plates were incubated at $37^{\circ} \mathrm{C}$ for 24 hours while for fecal coliforms, plates were incubated at $44.5^{\circ} \mathrm{C}$ for 24 hours. For fungal assay, plates were incubated at $25^{\circ} \mathrm{C}$ for 48 hours. For the isolation of Escherichia coli and Klebsiella spp., $0.1 \mathrm{ml}$ suspension was spread over MacConkey agar and incubated at $37^{\circ} \mathrm{C}$ for $18-24$ hours. Presence of $E$. coli was further confirmed by the appearance of bluish-black colonies with green metallic sheen on Eosin-Methylene Blue (EMB) agar.

One $\mathrm{ml}$ of homogenized sample was transferred to $9 \mathrm{ml}$ of selenite cystine broth for the enrichment of Shigella spp. and Salmonella spp., and also to the alkaline peptone water for the enrichment of Vibrio spp., followed by incubation at $37^{\circ} \mathrm{C}$ for 6 hours (Acharjee et al., 
2013). From each of the $10^{-4}$ to $10^{-6}$ dilutions of the enriched broth, $0.1 \mathrm{ml}$ of suspension was spread onto Xylose Lysine Deoxycholate (XLD) and Thiosulphate Citrate Bile Salt Sucrose (TCBS) agar plates. After incubation at $37^{\circ} \mathrm{C}$ for 24 hours, characteristic colonies were enumerated. For the isolation of Clostridium perfringens, each sample was mixed in sterile saline in a ratio of $1: 8$ and was heated at $80^{\circ} \mathrm{C}$ for 15 minutes in order to kill vegetative cells. Then $1 \mathrm{ml}$ of the suspension was kept in $9 \mathrm{ml}$ fluid thioglycolate broth at $37^{\circ} \mathrm{C}$ for 4 hours. Afterward, from each of the $10^{-4}$ to $10^{-6}$ dilutions, $0.1 \mathrm{ml}$ of suspension was pour plated on Perfringens agar medium, and incubated at $37{ }^{\circ} \mathrm{C}$ in an anaerobic jar for 48 hours.

To isolate Listerria monocytogenes, 0.1 $\mathrm{ml}$ suspension from $10^{-3-10^{-6}}$ dilutions were spread onto Listeria isolation media and incubated at $37^{\circ} \mathrm{C}$ for 24 hours. Colonies appeared as olive green was enumerated. Finally, a series of biochemical tests were performed following the standard method to confirm the pathogenic identification (Cappuccino and Sherman, 1996).

\section{Determination of antimicrobial susceptibility}

Isolates were tested for antibiotic susceptibility against ampicillin $10 \mu \mathrm{g}$, amoxicillin $10 \mu \mathrm{g}$, ciprofloxacin $5 \mu \mathrm{g}$, chloramphenicol $10 \mu \mathrm{g}$, and gentamycin $10 \mu \mathrm{g}$ by the disc diffusion assay on Mueller-Hinton Agar (Difco, Detroit, MI) following the standard protocol (Bauer et al., 1968; Ferraro, 2001; Munshi et al., 2012).

\section{Results and Discussion: \\ Prevalence of pathogenic bacteria and fungi in collected samples}

The pathogenic load was much higher in fish samples than those in the prawn samples. In case of fishes, the total viable bacteria were found to be $3.3 \times 10^{9} \mathrm{cfu} / \mathrm{g}$ and $3.2 \times 10^{9} \mathrm{cfu} / \mathrm{g}$ for Channa and Catla fish samples, respectively (Table 1). The bacterial load was higher in case of Channa sp. detected as $4.2 \times 10^{7} \mathrm{cfu} / \mathrm{g}$ for Pseudomonas spp. whereas, Salmonella spp., Shigella spp., Vibrio spp., Listeria spp. and Staphylococcus spp. were found to be $3.0 \times 10^{6} \mathrm{cfu} / \mathrm{g}, 2.2 \times 10^{5} \mathrm{cfu} / \mathrm{g}$, $2.5 \times 10^{6} \mathrm{cfu} / \mathrm{g}, 2.6 \times 10^{5} \mathrm{cfu} / \mathrm{g}$ and $4.6 \times 10^{6} \mathrm{cfu} / \mathrm{g}$, respectively. For Catla, Staphylococcal load was observed to be $6.7 \times 10^{9} \mathrm{cfu} / \mathrm{g}$, while the loads of Salmonella spp., Shigella spp., Vibrio spp., and Pseudomonas spp. were $2.1 \times 10^{7} \mathrm{cfu} / \mathrm{g}, 3.1 \times 10^{7}$ $\mathrm{cfu} / \mathrm{g}, \quad 1.3 \times 10^{7} \mathrm{cfu} / \mathrm{g}$ and $2.6 \times 10^{7} \mathrm{cfu} / \mathrm{g}$, consecutively.

Collected prawn samples were free from Pseudomonas spp., Salmonella spp., Shigella spp. and Listeria spp. The total viable bacteria from prawn were estimated to be $2.6 \times 10^{8}$. Vibrio spp. and Staphylococcus spp. were isolated to be $1.3 \times 10^{6}$ and $3.6 \times 10^{7} \mathrm{cfu} / \mathrm{g}$, respectively (Table 1). Except prawn samples, fecal coliforms were detected as $3.3 \times 10^{5} \mathrm{cfu} / \mathrm{g}$ and $1.3 \times 10^{6} \mathrm{cfu} / \mathrm{g}$ for Channa and Catla samples, consecutively. Clostridium spp. was not found in any of the samples.

Fungal isolates were reported from all the samples. Channa sp. shows fungal load of $3.8 \times 10^{6}$ propagules/g Catla sp. shows $1.3 \times$ $10^{4}$ propagules/g and prawn sample shows 3.6 x $10^{5}$ propagules/g However, fungal growth was observed in all the samples.

\section{Antibiotic susceptibility patterns of bacteria}

Most of the pathogenic isolates showed higher rates of resistance against ampicillin, ciprofloxacin, amoxicillin, and chloramphenicol (Table 3). On the other hand, the isolates were found to be sensitive against gentamycin.

Table 1. Prevalence of pathogenic microorganisms in collected fish samples

\begin{tabular}{|c|c|c|c|c|c|c|c|c|c|c|}
\hline $\begin{array}{l}\text { Fish } \\
\text { samples }\end{array}$ & \begin{tabular}{l|} 
Total \\
viable \\
Bacteria \\
$(\mathrm{cfu} / \mathrm{g})$
\end{tabular} & $\begin{array}{l}\text { Total } \\
\text { fecal } \\
\text { Coliform } \\
\text { (cfu /g) }\end{array}$ & $\begin{array}{l}\text { Fungi } \\
\text { (propagules } \\
\text { /g) }\end{array}$ & $\begin{array}{l}\text { Pseudomona } \\
\text { spp. } \\
\text { (cfu/g) }\end{array}$ & \begin{tabular}{|l|} 
Salmonella \\
spp. \\
$(\mathrm{cfu} / \mathrm{g})$
\end{tabular} & $\begin{array}{l}\text { Shigella } \\
\text { spp. } \\
\text { (cfu/g) }\end{array}$ & $\begin{array}{l}\text { Vibrio } \\
\text { spp. } \\
\text { (cfu/g) }\end{array}$ & $\begin{array}{l}\text { Listeria } \\
\text { spp. } \\
\text { (cfu/g) }\end{array}$ & $\begin{array}{l}\text { Staphylo } \\
\text {-coccus } \\
\text { spp. } \\
\text { (cfu/g) }\end{array}$ & $\begin{array}{l}\text { Clostridium } \\
\text { spp. } \\
(\mathrm{cfu} / \mathrm{g})\end{array}$ \\
\hline $\begin{array}{l}\text { Channa } \\
\text { spp. }\end{array}$ & $\begin{array}{l}3.3 \times 10^{9} \\
(0.001)\end{array}$ & $\begin{array}{l}3.3 \times 10^{5} \\
(0.001)\end{array}$ & $\begin{array}{l}3.8 \times 10^{6} \\
(0.001)\end{array}$ & $\begin{array}{l}4.2 \times 10^{7} \\
(0.001)\end{array}$ & \begin{tabular}{|l|}
$3.0 \times 10^{6}$ \\
$(0.001)$
\end{tabular} & $\begin{array}{l}2.2 \times 10^{5} \\
(0.0122)\end{array}$ & $\begin{array}{l}2.5 \times 10^{6} \\
(0.0054)\end{array}$ & $\begin{array}{l}2.6 \times 10^{5} \\
(0.0495)\end{array}$ & $\begin{array}{l}4.6 \times 10^{6} \\
(0.001)\end{array}$ & $\begin{array}{l}0 \\
(0.0)\end{array}$ \\
\hline $\begin{array}{l}\text { Catla } \\
\text { spp. }\end{array}$ & $\begin{array}{l}3.2 \times 10^{9} \\
(0.001)\end{array}$ & $\begin{array}{l}1.3 \times 10^{6} \\
(0.0885)\end{array}$ & $\begin{array}{l}1.3 \times 10^{4} \\
(0.0885)\end{array}$ & $\begin{array}{l}2.6 \times 10^{7} \\
(0.004)\end{array}$ & \begin{tabular}{|l|}
$2.1 \times 10^{7}$ \\
$(0.0158)$
\end{tabular} & $\begin{array}{l}3.1 \times 10^{7} \\
(0.001)\end{array}$ & $\begin{array}{l}1.3 \times 10^{7} \\
(0.0885)\end{array}$ & $0(0.0)$ & $\begin{array}{l}6.7 \times 10^{9} \\
(0.001)\end{array}$ & $\begin{array}{l}0 \\
(0.0)\end{array}$ \\
\hline Prawn & $\begin{array}{l}2.6 \times 10^{8} \\
(0.004)\end{array}$ & $0(0.0)$ & $\begin{array}{l}3.6 \times 10^{5} \\
(0.001)\end{array}$ & $0(0.0)$ & $0(0.0)$ & $0(0.0)$ & $\begin{array}{l}1.3 \times 10^{6} \\
(0.0885)\end{array}$ & $0(0.0)$ & $\begin{array}{l}3.6 \times 10^{7} \\
(0.001)\end{array}$ & $0(0.0)$ \\
\hline
\end{tabular}

Average count (cfu/g) from all samples have been shown here.

1 Bacterial load after enrichment (Prior to enrichment, the recovery was nil).

All data were statistically analyzed and were found significant $(\mathrm{p}<0.1)$. Respective $\mathrm{p}$-values have been indicated in parentheses.

Table 2. Biochemical identification of the pathogenic isolates 


\begin{tabular}{|c|c|c|c|c|c|c|c|c|c|c|}
\hline \multirow{2}{*}{$\begin{array}{l}\text { Assumed } \\
\text { Pathogenic } \\
\text { microorganisms }\end{array}$} & \multicolumn{3}{|l|}{ TSI } & \multirow{2}{*}{$\begin{array}{l}\mathrm{H}_{2} \mathrm{~S} \\
\text { reaction }\end{array}$} & \multirow{2}{*}{$\begin{array}{l}\text { Indole } \\
\text { test }\end{array}$} & \multirow{2}{*}{$\begin{array}{l}\text { MR } \\
\text { test }\end{array}$} & \multirow{2}{*}{$\begin{array}{l}\mathrm{VP} \\
\text { test }\end{array}$} & \multirow{2}{*}{$\begin{array}{l}\text { Citrate } \\
\text { test }\end{array}$} & \multirow[t]{2}{*}{ Motility } & \multirow{2}{*}{$\begin{array}{l}\text { Oxidase } \\
\text { test }\end{array}$} \\
\hline & Slant & Butt & Gas & & & & & & & \\
\hline Catlaella spp. & $\mathrm{R}$ & $\mathrm{Y}$ & - & + & - & + & - & - & + & \\
\hline Shigella spp. & $\mathrm{R}$ & $\mathrm{Y}$ & - & - &,+- & + & - & - & - & \\
\hline Vibrio spp. & $\mathrm{Y}$ & $\mathrm{Y}$ & - & - & + & + & + & - & + & + \\
\hline Staphylococcus spp. & $\mathrm{Y}$ & $\mathrm{R}$ & + & + & - & + & - & + & + & - \\
\hline Listeria spp. & $\mathrm{Y}$ & $\mathrm{Y}$ & - & - & - & + & + & - & + & - \\
\hline Pseudomonas spp. & $\mathrm{R}$ & $\mathrm{R}$ & - & - & - & - & - & + & + & + \\
\hline
\end{tabular}

TSI=Triple Sugar Iron Test, Y=Yellow (Acid), R=Red (Alkaline), MR=Methyl red, VP=Voges-Proskauer

Table 3. Antibiogram of the pathogenic isolates

\begin{tabular}{|c|c|c|c|c|c|c|c|c|c|c|c|c|}
\hline \multirow[t]{2}{*}{$\begin{array}{l}\text { Organisms } \\
\text { Antibiotics }\end{array}$} & \multicolumn{2}{|c|}{$\begin{array}{l}\text { Shigella } \\
\text { spp. } \\
\mathrm{N}=15\end{array}$} & \multicolumn{2}{|c|}{$\begin{array}{l}\text { Salmonella } \\
\text { spp. } \\
\mathrm{N}=15\end{array}$} & \multicolumn{2}{|c|}{$\begin{array}{l}\text { Vibrio } \\
\text { spp. } \\
\mathrm{N}=15\end{array}$} & \multicolumn{2}{|c|}{$\begin{array}{l}\text { Listeria } \\
\text { spp. } \\
\mathrm{N}=15\end{array}$} & \multicolumn{2}{|c|}{$\begin{array}{l}\text { Staphylococcus } \\
\text { spp. } \\
\mathrm{N}=15\end{array}$} & \multicolumn{2}{|c|}{$\begin{array}{l}\text { Pseudomonas } \\
\text { spp. } \\
\mathrm{N}=15\end{array}$} \\
\hline & $\mathrm{R}$ & $\mathrm{S}$ & $\mathrm{R}$ & $\mathrm{S}$ & $\mathrm{R}$ & $S$ & $\mathrm{R}$ & $\mathrm{S}$ & $\mathrm{R}$ & S & $\mathrm{R}$ & $S$ \\
\hline AMP & $79 \%$ & $21 \%$ & $77 \%$ & $23 \%$ & $85 \%$ & $15 \%$ & $95 \%$ & $5 \%$ & $85.5 \%$ & 14.5 & $90 \%$ & $10 \%$ \\
\hline AMO & $27 \%$ & $73 \%$ & $10 \%$ & $90 \%$ & $\mathrm{ND}$ & $\mathrm{ND}$ & $82 \%$ & $18 \%$ & $80 \%$ & $20 \%$ & $75 \%$ & $25 \%$ \\
\hline CIP & $90 \%$ & $10 \%$ & $85 \%$ & $15 \%$ & $11 \%$ & $89 \%$ & $68 \%$ & $32 \%$ & $\mathrm{ND}$ & ND & $60.5 \%$ & $39.5 \%$ \\
\hline $\mathrm{CHL}$ & $60 \%$ & $40 \%$ & $65 \%$ & $35 \%$ & $36 \%$ & $64 \%$ & $25 \%$ & $75 \%$ & $\mathrm{ND}$ & ND & $25.5 \%$ & $74.5 \%$ \\
\hline GEN & $0 \%$ & $100 \%$ & $25 \%$ & $75 \%$ & $\mathrm{ND}$ & ND & $14 \%$ & $86 \%$ & $24.5 \%$ & $75.5 \%$ & $10 \%$ & $90 \%$ \\
\hline
\end{tabular}

All the experiments have been done in triplicates and the results were reproducible. One representative data have been shown.

AMP $(10 \mu g)=$ Ampicillin, AMO $(10 \mu g)=$ Amoxicillin, CHL $(10 \mu g)=$ Chloramphenicol, GEN $(10 \mu g)=$ Gentamycin, $\mathrm{ND}=$ Not done, $\mathrm{N}=$ Number of isolates, $\mathrm{R}=$ Resistance, $\mathrm{S}=$ Sensitive

Fish is one of the favorite and easily available food items in rural India. However, fish borne diseases may put the overall public health at a serious risk (Novotny et al., 2004). Most of the cases of morbidity and mortality have been reported due to the proliferation of bacterial pathogens (Butt et al., 2004). However, no detailed pathogenic study of fishes has been carried out in India so far. Thus, the pathogenic study in the consumable fishes asks for an emerging demand as priority for the sake of consumer health and maintenance of fish quality.

The maximum bacterial counts for fresh and frozen fish samples recommended as $5 \times 10^{5}$ $\mathrm{cfu} / \mathrm{g}$ (ICMSF, 1986). In the present study, fish samples exceed this limit for bacterial count, thereby, demonstrating a substantial risk on the public health. The quality of the fish and fish products largely depends on the interval between the harvesting and processing time. During this period, fishes continue to deteriorate (Antony et al., 2002). Moreover, handling and processing without maintaining asepsis result in pathogenic growth which renders the food products to be spoiled. An important aspect revealed from the current study is that most of the pathogens were found to be resistant against commonly used antibiotics thereby demonstrating the ineffectiveness of the treatment during disease outbreaks if any. Such a situation hinders disease eradication and hence poses a fatal effect on the public health and community. However, in India, probably due to poor settings as well as for the lack of appropriate knowledge on fish borne pathogens, the microbiological risk exposed by fish and fish products is obscure. Present study thus endeavored to establish a complete data on the pathogens associated with the fish samples studied and hence is of significance.

It is worth mentioning that, a lot of molecular studies established that the contaminated food containing pathogenic microbes may harbor virulence genes which become responsible for many of the food borne disease outbreaks (Gubala and Proll, 2006; Bhatta et al., 2007; Jakee et al., 2009; Munshi et al., 2012). Thus, the finding of the present study indicates the high risk of such virulent genes existence which may propagate from the habitant pathogenic isolates. Therefore, further study would unveil the molecular etiology of fish borne diseases.

Overall, the current findings reveal that fishes and prawns may harbor pathogenic microorganisms above the acceptable limit, 
indicating that these fish samples have not been protected from the microbial spoilage during handling, storage, and transport. Appropriate maintenance of microbiological quality is thus a vital aspect of quality control measures of such fishes.

\section{Acknowledgement:}

Author thanks Center for Higher Learning and Research, Microbiology Department, Sardar Patel College, Chandrapur, MS for identification of pathogenic isolates.

\section{References:}

[1] Acharjee, M., Kaniz, F., Jahan, F., Siddique, S. J., Uddin, M. A. and Noor, $R$. (2013): Prewvalence of Vibrio cholera in different food samples in the city of Dhaka, Bangladesh. International Food Research Journal 20 (2): 1017-1022.

[2] Antony, M. M., Jeyasekaran, G., Shakila, R. J. and Shanmugam, S. A. (2002): Microbiological Quality of Raw Shrimps Processed in Seafood Processing Plants of Tuticorin, Tamil Nadu, India. Asian Fisheries Science 15: Pp. 33-41.

[3] Bauer, A. W., Kirby, w. M. M., Sherris, J. C. and Tierch, M. (1968): Antibiotic susceptibility testing by a standardized single disc method. American Journal of Clinical Pathology 45(4): Pp. 493-496.

[4] Bhatta, D. R., Bangtrakulnonth, A., Tishyadhigama, P., Saroj, S. D., Bandekar, J. R., Hendriksen, $R$. S. and Kapadnis, B. P. (2007): Serotyping, PCR, phage-typing and antibiotic sensitivity testing of Salmoella serovars isolated from urban drinking water supply systems of Nepal. Letters in Applied Microbiology 44(6): Pp.588-94.

[5] Butt, A. A., Aldridge, K. E., and Sanders, C. V. (2004): Infections related to the ingestion of seafood Part I: viral and bacterial infections. The Lancet Infectious Diseases 4: Pp. 201-212.

[7] Cappuccino, J. G. and Sherman, N. (1996): Microbiology - A Laboratory Manual. 4th edn. California: The Benjamin/Cummings Publishing Co., Inc.

[8] Cray, W. C. J. and Moon, H. W. (1995): Experimental infection of calves and adult cattle with Escherichia coli O157:H7. Applied Environmental Microbiology 61(4): Pp.15861590.

[9] Dinakaran, G. K., Soundarapandian, P. and Tiwary, A. K. (2010): Nutritional status of edible Palaemonid Prawn Macrobrachium scabriculum. European Journal of Applied Science 2(1): Pp. 30-36.
[10] Eze, E. I., Echezona, B. C. and Uzodinma, E. C. (2011): Isolation and identification of pathogenic bacteria associated with frozen mackerel fish (Scomber scombrus) in a humid tropical environment. African Journal of Agricultural Research 6(7): Pp.1918-1922.

[11] Ferraro, M. J., Craig, W. A. and Dudley, M. N. (2001): Performance standards for antimicrobial susceptibility testing. 11th edn. Pennsylvania, USA: NCCLS.

[12] Frazier, W. C. and Westhoff, D. C. (1995): Contamination, preservation, and spoilage of fish and other seafoods. In Food Microbiology, p. 243. 4th edn. New Delhi: Tata Mcgraw-Hill publishing company ltd.

[13] Gubala, A. J. and Proll, D. F. (2006): Molecular-Beacon Multiplex Real-Time PCR Assay for Detection ofVibrio cholerae. Applied Environmental Microbiology 72(9): Pp. 64246428.

[14] International Commission on Microbiological Specifications for food (ICMSF) (1986): Microorganisms in food sampling for microbiological analysis: Principle and specific application. 2nd edn. Blackwell Scientific Publication.

[15] Jakee, J. E., Moussa, E. I., Mohamed, K. F. and Mohamed, G. (2009): Using Molecular Techniques for Characterization of Escherichia coli Isolated from Water Sources in Egypt. Global Veterinaria 3(5): Pp. 354-362.

[16] Karunasagar, I., Pai, R., Malathi, G. R., and Karunasagar, I. (1994): Mass mortality of Penaeus monodon larvae due to antibiotic resistant Vibrio harveyi infection. Aquaculture 128: Pp. 203-209.

[17] Kawarazuka, N. (2010): The contribution of fish intake, agriculture, and small scale fisheries to improve nutrition: aliterature review. Report paper of World Fish Center. Penang, Malaysia.

[18] Mead, J. F., Alfin-Slater, R. B., Howton, D. R. and Popják, G. (1986): Lipids: Chemistry, Biochemistry and Nutrition, p. 486. New York: Plenum Press.

[19] Mol, S., Erkan, N., Ucok, D. and Tosun, Y. S. (2007): Effect of psychrophilic bacteria to estimate fish quality. Journal of Muscle Foods 18: Pp. 120-128.

[20] Munshi, S. K., Rahman, M. M. and Noor, R. (2012): Detection of virulence potential of diarrheagenic Escherichia coli isolated from surface water of rivers surrounding Dhaka City. Journal of Bangladesh Academy of Sciences 36 (1): Pp.109-122. 
[21] Novotny, L., Dvorska, L., Lorencova, A., Beran, V. and Pavlik, L. (2004) Fish: a potential source of bacterial pathogens for human beings. Veterinary Medicine 9: Pp. 343358.

[22] Snowdon, J. A., Cliver, D. O. and Converse, J. C. (1989): Land disposal of mixed human and animal wastes: a review. Waste Management Research 7: Pp. 121-134.
[23] Starutch, D. (1991): Survival of pathogenic microorganisms and parasites in excreta, manure sand sewage sludge. Review of Science and Technology 10 (3): Pp. 813-846.

[24] Wallace, B. J., Guzewich, J. J., Cambridge, M., Altekruse, S. and Morse, D. L. (1999): Seafood-Associated Disease outbreaks in New York, 1980-1994. American Journal of Preventive Medcine 17 (1): Pp. 48-54. 